\title{
HUBUNGAN ANTARA ORIENTASI RELIGIUS DAN DUKUNGAN SOSIAL DENGAN KEDISIPLINAN BERIBADAH PADA WARGA GEREJA
}

\author{
Yoyok Ellyazar \\ Universitas Mercu Buana Yogyakarta \\ E-mail: sulistyorini_hp@yahoo.com
}

\begin{abstract}
Abstrak : Hubungan Antara Orientasi Religius dan Dukungan Sosial dengan Kedisiplinan Beribadah Pada Warga Gereja. Penelitian ini bertujuan untuk menguji secara empirik hubungan antara orientasi religius dengan kedisiplinan beribadah, hubungan antara dukungan sosial dengan kedisiplinan beribadah dan hubungan antara orientasi religius dan dukungan sosial secara bersama-sama dengan kedisplinan beribadah. Subjek dalam penelitian ini adalah warga Gereja Kristen Jawa Ngento-ento yang berjumlah 81 orang. Pengumpulan data dilakukan dengan skala orientasi religius, skala dukungan sosial, dan skala kedisiplinan beribadah. Analisis data menggunakan teknik analisis korelasi product moment dari Pearson dan analisis regresi linier berganda. Hasil analisis korelasi product moment ternyata 1) ada hubungan positif yang signifikan antara orientasi religius dengan kedisiplinan beribadah, nilai korelasi 0,700 ( $<<0,05)$. 2) ada hubungan positif dan signifikan antara dukungan sosial dengan kedisiplinan beribadah nilai korelasi $0,471(\mathrm{p}<0,05) .3)$ bahwa orientasi religius dan dukungan sosial secara bersama-sama berpengaruh secara signifikan terhadap kedisiplinan beribadah, nilai signifikansi $0,000<0,05$. Berarti, hipotesis yang diajukan terbukti dan dapat diterima. Sumbangan efektif orientasi religius dan dukungan sosial terhadap kedisiplinan beribadah sebesar $53,5 \%$, sedangkan $46,5 \%$ dipengaruhi oleh faktor lain yang tidak dilibatkan dalam penelitian ini.
\end{abstract}

Kata kunci: Orientasi Religius, Dukungan Sosial, dan Kedisiplinan Beribadah

\begin{abstract}
Relationship between Religious Orientation and Social Support with Worship Dicipline of The Church Community. The purposes of this research are to empirically examine the relationship between religious orientation and worship discipline, the relationship between social support and worship discipline, and the relationship between religious orientation together with social support and worship discipline. The hypotheses proposed are (1) there is a positive relationship between religious orientation and worship discipline; (2) there is a positive relationship between social support and worship discipline; (3) there is a relationship between religious orientation together with social support and worship discipline. The subject of this research was the Church member of Javanese Christian Church of Ngento-ento, with the total number of 81 people. The data was collected by using religious orientation scale, social support scale and worship discipline scale. The data was analyzed by using the Pearson product-moment correlation analysis for the first and second hypotheses and multiple regression analysis for the third hypothesis. The result of product-moment correlation analysis for the first hypothesis showed correlation value $0,700(p<0.05)$, therefore there was a positive relationship between religious orientation and worship discipline; The result of product-moment correlation analysis for the second hypothesis showed correlation value $0.471(\mathrm{p}<0.05)$, therefore there was a positive relationship between social support and worship discipline; The result of multiple regression analysis for the third hypothesis with significance value 0.000 $<0.05$ which mean religious orientation together with social support significantly influenced worship discipline. Therefore the hypotheses proposed were proven and accepted. The effective influence of religious orientation and social support toward the worship discipline was $53,5 \%$ while the $46,5 \%$ was influenced by the other factors that were not involved in this research.
\end{abstract}

Keywords: religious orientation, social support, worship discipline. 


\section{PENDAHULUAN}

Dalam kehidupan manusia dijumpai aktivitas keagamaan (religius) yaitu beribadah. Ibadah merupakan komponen agama (religi) yang menjadi perwujudan kepercayaan para pemeluk agama. Aktivitas religius itu ada kaitannya dengan kebutuhan manusia untuk menyelenggarakan kehidupannya. Suseno (1988) mengatakan, agama sebagai sistem sosial yang memuat kepercayaan kepada sesuatu yang transenden. Kepercayaan tersebut diwujudkan dalam kelompok yang menyadari kesatuannya antara lain melalui ibadah.

Berkaitan dengan ibadah, Subandrijo (2003) mengemukakan pandangannya sebagai rasa bakti dan penyembahan kepada satu Kuasa yang diyakini bersifat Supranatural, dengan melibatkan seluruh segi kehidupan manusia. Penyembahan disimbolkan dalam bentuk ritus dan tatacara peribadahan dan harus diwujudkan dalam sikap terhadap sesama dan lingkungannya. Peribadahan tidak hanya menyangkut ritual dan berorientasi pada diri sendiri, tetapi harus dapat dirasakan pengaruhnya dalam konteks berbangsa, bermasyarakat, serta memberi sumbangan positif bagi kehidupan bersama sehingga agama menjadi berkat bagi manusia.

Stott (1996) mengemukakan bahwa makna ibadah adalah pengabdian kepada Tuhan yang berlangsung sepanjang hidup dan dipusatkan selama satu jam atau lebih dalam ibadah secara bersama-sama pada hari Minggu dan disaksikan oleh masyarakat umum. Jika semua yang dikatakan dan dinyanyikan dalam ibadah tidak mendampak dalam kehidupan sehari-hari di luar gereja, di rumah dan di tempat bekerja, maka kegiatan agamawi seperti itu bukan hanya tidak bermakna tetapi merupakan kemunafikan.

Berdasarkan pandangan di atas ditemukan gagasan mengenai ibadah dalam religi yang harus dipahami secara benar tujuan dan maknanya dalam kehidupan manusia. Ibadah adalah penyembahan terhadap Tuhan dalam seluruh segi kehidupan dan yang sekaligus jalinan hubungan yang baik dengan sesama.
Dalam Gereja Kristen Jawa terdapat ibadah Minggu, ibadah hari raya, ibadah khusus yang berkaitan dengan peristiwa-peristiwa tertentu seperti pernikahan, penahbisan pendeta, serta hari besar Nasional (Sinode GKJ, 2005). Warga gereja diharuskan untuk melaksanakan ibadah secara taat, tertib dan disiplin.

Ibadah yang dibicarakan dalam penelitian ini adalah hanya ibadah hari Minggu. Ibadah meliputi unsur-unsur yang ditetapkan untuk penghayatan relasi manusia dengan Tuhan dan relasi dengan sesama. Perilaku kedisiplinan beribadah warga gereja berada dalam konteks kehidupan yang berkembang dan berubah. Perubahan yang melahirkan modernisasi, sekularisasi, dan globalisasi merupakan kenyataan yang diakui memberi makna positif bagi kehidupan tetapi juga dicurigai karena membawa dampak negatif bagi manusia (Heitink, 1999).

Berdasarkan pengamatan terhadap warga gereja kaitannya dengan ibadah Minggu, ternyata ada warga gereja yang mengabaikan bahkan tidak beribadah Minggu tetapi lebih mementingkan urusan lain. Catatan majelis gereja diperoleh data bahwa warga gereja yang tidak hadir dalam ibadah Minggu mencapai 10 - 15 \%. Dalam hal melakukan unsur-unsur ibadah ada perbedaan sikap dan keaktifan antara warga yang satu dengan warga lainnya. Abineno (1999) mengatakan bahwa ibadah Minggu harus dilakukan oleh seluruh warga gereja untuk secara bersama-sama mengambil bagian dalam ibadah sebagai penyembahan Tuhan, bukan secara reseptif tetapi secara aktif dan disiplin sesuai dengan unsur-unsur ibadah yang ditentukan.

Istilah disiplin diartikan sebagai ketaatan dan kepatuhan pada aturan, dan tata tertib (Moeliono, 1990). Keith (dalam Sastropoetro, 1998) menjelaskan istilah disiplin sebagai pengawasan terhadap diri pribadi untuk melaksanakan segala sesuatu yang telah disetujui atau diterima sebagai tanggung jawab. Drever (1988), mengartikan disiplin sebagai kontrol terhadap kelakuan, baik oleh suatu kekuasaan luar ataupun oleh 
individu sendiri.

Jadi, kedisiplinan adalah ketaatan, kepatuhan, dan kontrol diri terhadap peraturan yang telah disetujui dan diterima, Dalam konteks kedisiplinan beribadah dimaksudkan sebagai ketaatan, kepatuhan, dan kontrol diri individu dalam menerima peraturan tentang peribadahan serta dalam melaksanakan ibadah secara aktif.

Penelitian tentang kedisiplinan beribadah diharapkan dapat menjadi cara untuk memperoleh gambaran mengenai sejauh mana warga gereja benar-benar memiliki pemahaman dan motivasi yang benar tentang ibadah dan ketika melaksanakannya. Dister (1989) berpendapat bahwa penyelidikan gejala agama dapat bahkan harus dilakukan karena merupakan gejala penting dalam kehidupan kejiwaan manusia. Meski ada kaitannya dengan agama tetapi objek yang diteliti bukan Allah tetapi manusia, yaitu manusia yang beragama. Tindakan beriman (percaya kepada Allah, menyerahkan diri kepada Allah) adalah tindakan manusiawi oleh karena itu terbuka untuk penyelidikan psikologi.

Menurut Hendriyani (2012) kedisiplinan dipengaruhi oleh faktor intern dan ekstern. Faktor intern di antaranya adalah pembawaan, kesadaran, minat, motivasi, dan pola pikir. Sedangkan faktor ekstern adalah dukungan sosial dalam bentuk keteladanan, nasihat, latihan, lingkungan, dan kelompok.

Faktor lain yang mempengaruhi kedisiplinan beribadah adalah orientasi religius. Earnshaw (dalam Hermapramni, 2012) mengatakan bahwa orientasi religius ditandai dengan motivasi beragama dan dalam hal ini ibadah ditonjolkan. Borgotta (dalam Hermapramni, 2012) mengatakan bahwa aspek esensi dari orientasi religius adalah keyakinan individu akan keberadaan Tuhan, hal baik dan jahat, kehidupan setelah kematian. Hal-hal tersebut dapat memengaruhi individu peserta penyembahan/ibadah.

Dari beberapa pendapat di atas penulis akan melihat kedisiplinan beribadah dari faktor orientasi religius dan dukungan sosial, karena kedua faktor tersebut merupakan faktor yang paling mendasar dalam mempengaruhi kedisi-plinan, khususnya terkait dengan kedisi-plinan beribadah.

Menurut Setiyartomo (dalam Hermapramni, 2012) orientasi religius adalah cara seseorang mempraktikkan keyakinankeyakinan dan nilai-nilai keagamaannya. Allport dan Ross (dalam Widyana, 1995) mengajukan suatu tipologi psikologis orientasi religius ke dalam klasifikasi intrinsik dan ekstrinsik. Individu yang memiliki orientasi religius intrinsik adalah individu yang menunjukkan motivasi utama dalam agama yang dianut, dan mengkonsentrasikan pada kepentingan agama, sehingga agama dipahami sebagai pemandu dan pengatur seluruh hidup. Sedangkan individu dengan orientasi religius ekstrinsik adalah individu yang cenderung memanfaatkan agama demi kepentingan-kepentingannya sendiri, sehingga cenderung memandang agama menurut kerangka kegunaan dan mengembangkan keyakinan agama secara selektif.

Dalam konteks kedisiplinan beribadah, individu yang memiliki orientasi religius intrinsik melaksanakan ibadah dengan kedisiplinan karena ibadah dipahami sebagai kewajiban agama yang menjadi pemandu dan pengarah kehidupannya. Sedangkan individu yang memiliki orientasi religius ekstrinsik melakukan ibadah sebagai kewajiban dari agama dengan mempertimbangkan kepentingan sendiri atau kegunaannya. Sehingga dapat dikatakan bahwa semakin intrinsik orientasi religius individu maka semakin tinggi kedisiplinan beribadah individu, sebaliknya semakin ekstrinsik orientasi religius individu, maka akan semakin rendah kedisiplinan beribadah individu.

Faktor lain sebagai variabel dalam penelitian ini adalah dukungan sosial, yang menurut Aronson (2005) diartikan sebagai pengalaman menerima pertolongan dari orang lain, dari keluarga dan teman-teman, serta mereka yang berhubungan dekat. Dukungan sosial terjadi ketika merasakan sikap dan tindakan orang lain yang tanggap 
dan mau memperhatikan apa yang diperlukan, sehingga merupakan hal yang sangat berarti.

Dalam konteks kedisiplinan beribadah, dukungan sosial adalah ketika individu memiliki pengalaman menerima dukungan dari keluarga dan teman-teman dalam perwujudan kedisiplinan beribadah. Jika dukungan sosial tinggi maka semakin tinggi kedisiplinan beribadah individu, sebaliknya semakin rendah dukungan sosial yang diterima individu maka semakin rendah kedisiplinan beribadah individu.

Penulis memiliki dugaan bahwa orientasi religius dan dukungan sosial dapat mempengaruhi kedisiplinan beriba-dah warga gereja. Oleh karena itu penulis ingin meneliti apakah ada hubungan antara orientasi religius dan dukungan sosial dengan kedisiplinan beribadah warga gereja.

\section{Kedisiplinan Beribadah}

Chaplin (2006) mengartikan disiplin sebagai kontrol penguasaan diri dengan tujuan menahan impuls (gerak hati) yang tidak diinginkan, atau kontrol penguasaan diri untuk mengabdi kebiasaan. Kata disiplin berasal dari bahasa Inggris discipline, yang diterjemahkan ketertiban (Echols, 2005). Sinclair (2001) memberikan arti kata disiplin dalam beberapa pengertian, yaitu: (1) sebagai praktek membuat orang mematuhi aturan atau standar perilaku, dan memberikan sanksi terhadap mereka yang tidak mematuhinya, (2) kualitas kemampuan berperilaku dan bekerja dengan cara yang terkendali, yang melibatkan aturan dan standar tertentu, (3) acuan yang diberlakukan untuk suatu aktivitas demi keberhasilan, (4) perilaku yang dikendalikan secara ketat untuk mematuhi peraturan-peraturan atau standar. Moeliono (1988) mengartikan disiplin sebagai ketaatan atau kepatuhan kepada peraturan atau tata tertib. Prijodarminto (1994) mengartikan disiplin sebagai suatu kondisi yang tercipta dan terbentuk melalui proses dari serangkaian perilaku yang menunjukkan nilai-nilai ketaatan, kepatuhan, kesetiaan, keteraturan, dan ketertiban. Arikunto (1990) mengartikan disiplin sebagai kepatuhan seseorang dalam mengikuti peraturan dan tata tertib karena didorong oleh adanya kesadaran yang ada di hatinya.

Chan (1998) mengemukakan bahwa kedisiplinan merupakan keteraturan (ritme) yang ditetapkan untuk membantu memelihara fokus rohani. Keteraturan yang dimaksud adalah perilaku yang mengikuti peraturan. Peck (2007) mengatakan bahwa disiplin merupakan perangkat mendasar yang dibutuhkan untuk mengembangkan spiritualitas.

Dari beberapa pengertian di atas dapat disimpulkan bahwa kedisiplinan adalah kesadaran, ketaatan, kepatuhan, kesetiaan, keteraturan, dan ketertiban dalam melaksanakan peraturan atau standar yang berlaku. Dalam penelitian ini kedisiplinan beribadah diartikan sebagai kesadaran, ketaatan, kepatuhan, kesetiaan, keteraturan, dan ketertiban dalam melaksanakan ibadah.

Tentang ibadah, Brown (1979) menjelaskan bahwa kata ibadah berasal dari bahasa Ibrani abodah, artinya pelayanan (labour service). Di lingkup keagamaan diartikan sebagai pelayanan penyembahan Allah dan untuk mengungkapkan rasa takut penuh hormat kekaguman dan penuh puja. Selain itu ibadah juga untuk mengungkapkan kasih dan syukur kepada Allah dalam tindakan rohani batiniah yang sungguh-sungguh.

Hardjana (1993) mengemukakan ibadah merupakan cara manusia untuk mengungkapkan pengakuan tentang Tuhan sebagai Asal, Penyelenggara dan Tujuan hidup. Kehidupan manusia terhubung dengan Tuhan dan melalui ibadah hubungan manusia dengan Tuhan dihayati, Tuhan disapa, dipuja, dipuji, dihormati, diluhurkan dan dimuliakan.

Peschke (2003) mengatakan bahwa ibadah terkait dengan pengalaman manusia dengan Yang Suci yang diwarnai oleh rasa hormat, iman, ketakutan, kepercayaan, cinta dan rasa kagum. Underhill (dalam White, 2002) mengemukakan bahwa ibadah dalam semua derajat dan jenisnya merupakan tanggapan dari ciptaan terhadap Yang Abadi. 
Dari beberapa pandangan di atas dapat disimpulkan bahwa ibadah merupakan cara manusia untuk mengungkapkan pengakuan tentang Tuhan dalam bentuk ritual yang dinyatakan dalam kehidupan sehari-hari. Dalam konteks kedisiplinan beribadah, yang dimaksud dengan kedisiplinan beribadah adalah kesadaran, ketaatan, kepatuhan, kesetiaan, keteraturan, dan ketertiban dalam melaksanakan ibadah. Fokus penelitian adalah bagaimana individu memberlakukan kedisiplinan beribadah, dalam hal ini ibadah Minggu dilihat dari kehadiran dan keaktifan dalam melaksanakan unsur-unsur ibadah.

Anshari (1983) mengatakan bahwa menanamkan kedisiplinan sebagai proses pendidikan dapat dilakukan dengan langkahlangkah, yaitu pembiasaan, keteladanan, penyadaran, dan pengawasan atau kontrol. Dalam konteks kedisiplinan beribadah, penanaman kedisiplinan sebagai proses pendidikan dalam melaksanakan ibadah bagi warga gereja dapat dilaksanakan sebagai berikut: pembiasaan dalam keluarga, keteladanan dari orang yang memiliki pengaruh dan majelis gereja sebagai pemimpin dalam gereja, penyadaran berupa nasihat dan arahan majelis gereja, pengawasan atau kontrol yang dilakukan oleh majelis gereja.

Irmim dan Rochim (2004) menjelaskan aspek-aspek kedisiplinan. Pertama, sikap mental (mental attitude), taat, tertib, dan pengendalian diri. Kedua, pemahaman atau kesadaran mengenai sistem aturan perilaku, norma, kriteria, dan standar untuk mencapai keberhasilan. Ketiga, sikap kesungguhan hati untuk mentaati segala hal secara cermat dan tertib. Dalam penelitian ini kedisiplinan beribadah akan diungkap melalui aspekaspek seperti tersebut di atas.

Hendriyani (2012) mengatakan bahwa kedisiplinan dipengaruhi oleh faktor intern dan faktor ekstern. Faktor intern di antaranya adalah: pembawaan, kesadaran, minat, motivasi, dan pola pikir. Faktor ekstern adalah dukungan sosial dalam bentuk keteladanan, nasihat, latihan, lingkungan, dan kelompok.
Faktor internal lain yang mem-pengaruhi kedisiplinan dalam hal ini kedisiplinan beribadah adalah orientasi religius. Earnshaw (dalam Hermapramni, 2012) mengatakan orientasi religius ditandai dengan motivasi beragama dan dalam hal ini sisi ibadah yang ditonjolkan. Borgotta (dalam Herma-pramni, 2012) mengatakan bahwa aspek esensi dari orientasi religius adalah keyakinan individu akan keberadaan Tuhan, hal baik dan jahat, kehidupan setelah kematian. Hal-hal tersebut dapat memengaruhi individu sebagai peserta penyembahan/ibadah. Dalam konteks kedisiplinan beribadah faktor keturunan, kesadaran, minat, motivasi, dan pola pikir, juga dipandang sebagai faktor-faktor yang mempengaruhi individu warga gereja dalam malaksanakan ibadah.

Taylor (2009) mengatakan bahwa faktor eksternal yang memberi pengaruh sosial terhadap individu adalah perilaku orang lain, norma kelompok, dan konteks kultural individu. Tiga tipe pengaruh sosial yang penting adalah konformitas (penyesuaian), ketundukan dan kepa-tuhan. Individu menyesuaikan perilaku, tunduk dan patuh karena ingin bertindak benar, agar disukai dan memenuhi kewajiban moral.

Dalam penelitian ini yang menjadi fokus perhatian adalah orientasi religius dan dukungan sosial. Orientasi religius sebagai faktor yang diduga menentukan individu dalam kedisiplinan beribadah, demikian juga dukungan sosial merupakan cerminan kehidupan bersama yang di dalamnya tiap individu saling berinteraksi, saling memengaruhi, dan saling mendukung termasuk dalam mewujudkan kedisiplinan beribadah.

\section{Orientasi Religius}

Heuken (2004) mengatakan bahwa kata religius berasal dari kata religi, dalam bahasa Inggris religion yang berarti agama (religi). Kata religius menyatakan sifat dari religi, yang dalam bahasa Indonesia diartikan dengan keagamaan atau yang bersifat agama. Religi atau religion dalam bahasa Latin religio, kata kerja relegere artinya 
memperhatikan dengan teliti pelaksanaan ritus-ritus dan religare artinya mengikat lagi atau reeligere artinya memilih lagi. Secara fenomenologis agama mencakup gejalagejala yang berkaitan dengan hubungan khusus antara manusia dan yang melampaui manusia (transenden) atau yang Maha Kudus.

Douglas (1999) mengatakan bahwa kata agama juga dipadankan dengan kata dalam bahasa Yunani threskia, artinya ungkapan lahiriah dari kepercayaan, yang juga diterjemahkan ibadah. Setiawan (1997) mengatakan bahwa agama adalah aturan atau tatacara hidup manusia dalam hubungannya dengan Tuhan dan sesamanya. Agama juga disebut pedoman hidup manusia, pedoman bagaimana individu harus berpikir, bertingkah laku dan bertindak untuk terciptanya suatu hubungan serasi antar manusia dan hubungan yang erat dengan Yang Maha Pencipta.

Menurut Dister (1989) sikap keagamaan (religius) adalah hubungan yang dihayati manusia dengan yang transenden atau Tuhan. Hubungan tersebut bersifat lahir-batin. Dari segi batin, agama menyangkut perasaan, keinginan, harapan, dan keyakinan yang dimiliki manusia terhadap yang transenden itu. Dari segi lahir, agama menyangkut tingkah laku tertentu yang mengungkapkan segi batin tadi ke dalam praktek kehidupan.

Berdasarkan pandangan-pandangan di atas dapat disimpulkan bahwa agama atau religi adalah sistem kepercayaan yang muncul dari kesadaran akan ketergantungan manusia kepada yang transenden dan yang dihayati melalui ritual ibadah yang dinyatakan dalam kehidupan sehari-hari. Religius diartikan sebagai sifat keagamaan ketika individu menunjukkan perilaku taat pada agama.

Kata orientasi dalam bahasa Inggris orientation diartikan sebagai suatu pengetahuan mengenai posisi seseorang dalam ruang dan waktu, satu titik pandangan atau satu kerangka referensi (Chaplin, 2006). Moeliono (1988) mengartikan orientasi sebagai kecenderungan pandangan atau menitikberatkan pandangan, berkiblat.

Dalam konteks orientasi religius, orientasi dipahami sebagai sikap atau kecenderungan religius individu, yang menurut Allport dan Ross (dalam Widyana, 1995) dikategorikan sebagai orientasi religius intrinsik atau ekstrinsik. Orientasi religius merupakan komitmen individu dalam kehidupan yang menjadikan religi sebagai titik pandangan atau kerangka referensi. Individu yang memiliki orientasi religius intrinsik menjadikan agama sebagai bentuk penghayatan kehidupan dan sumber kekuatan yang meyakinkan untuk menghadapi kehidupan dan memberikan pengarahan serta bantuan dalam pemecahan masalahmasalah kehidupan. Orientasi religius ketika menjadi identitas diri yang diikuti dengan cara penghayatan yang benar akan memberi bentuk aktualisasi diri yang dapat dipertanggung-jawabkan.

Menurut Setiyartomo (dalam Hermapramni, 2012) orientasi religius adalah cara seseorang mempraktekkan keyakinankeyakinan dan nilai-nilai keagamaannya. Earnshaw (dalam Hermapramni, 2012) mengatakan bahwa orientasi religius ditandai dengan motivasi beragama. Dalam hal ini sisi ibadah yang ditonjolkan, kehidupan beragama sehari-hari, dampak sosial beribadah, dan jalan keluar dalam mengatasi kesulitan.

Dari pandangan-pandangan di atas dapat disimpulkan bahwa orientasi religius adalah sikap atau kecenderungan pandangan individu yang diarahkan atau berkiblat pada Tuhan dan yang dinyatakan dalam kehidupan sehari-hari termasuk melalui ibadah.

Allport dan Ross (dalam Widyana, 1995) mengajukan suatu tipologi psikologis orientasi religius ke dalam klasifikasi intrinsik dan ekstrinsik. Pertama, orientasi religius intrinsik. Allport (dalam Feist, 2008) mengemukakan pandangan bahwa kelompok yang memiliki orientasi religius intrinsik cenderung menghayati agama dan menemukan penguasaan motif mereka berdasarkan iman kepada-Nya. Mereka menggunakan agama sebagai tujuan akhir dan mengakomodasi 
kebutuhan orang lain agar bisa harmoni dengan nilai-nilai religius mereka. Orangorang yang seperti ini menginternalisasikan iman dan mengikutinya dengan sepenuh hati. Orientasi religius intrinsik adalah keputusan beragama sebagai orientasi dalam kehidupan berdasarkan dorongan atau inisiatif dan benar-benar diyakini dari dalam diri individu, bukan karena alasan lain dari luar dirinya.

Kedua, orientasi religius ekstrinsik. Allport (dalam Feist, 2008) mempunyai asumsi bahwa manusia dengan orientasi ekstrinsik memiliki pandangan yang bersifat utilitarian terhadap agama, artinya melihat agama bukan sebagai tujuan akhir. Agama yang mereka pegang agar memberikan rasa aman dan ikatan sosial. Iman tidak terlalu dipegang erat-erat dan mudah sekali berubah jika perubahan memberi rasa nyaman yang lebih besar.

Hunt dan King mengembangkan konsep orientasi religius intrinsik-ekstrinsik yang dikemukakan oleh Allport dan Ross (dalam Widyana, 1995) sebagai berikut: personalinstitusional, unselfish-selfish, relevansi terhadap keseluruhan kehidupan, kepenuhan penghayatan keyakinan, Pokok-instrumental, asosiasional-komunal, keteraturan penjagaan perkembangan iman.

Dalam penelitian ini orientasi religius akan diungkap dengan mengacu pada teori Allport dan Ross, yaitu orientasi religius ekstrinsik-intrinsik yang dikembangkan oleh Hunt dan King (dalam Widyana, 1995). Semakin tinggi skor yang diperoleh subjek, semakin intrinsik orientasi religiusnya, sebaliknya semakin rendah skor yang diperoleh subjek, semakin ekstrinsik orientasi religiusnya.

\section{Dukungan Sosial}

Zanden (1984) mengemukakan bahwa kehidupan manusia berisi interaksi sosial, suatu proses yang diarahkan, dirangsang, dipengaruhi oleh orang lain. Cara berperilaku dipengaruhi oleh relasi-relasinya dengan orang lain merupakan bentuk dukungan sosial. Sehingga dapat dikatakan bahwa ada dua kebutuhan dasar sosial manusia, yaitu kebersamaan dan dimiliki serta kebutuhan untuk memperoleh dukungan sosial dari lingkungannya.

Aronson (2005) mengatakan bahwa dukungan sosial merupakan pengalaman menerima pertolongan dari orang lain, seperti dari keluarga dan teman-teman. Dukungan sosial terjadi ketika merasakan sikap dan tindakan orang lain yang tanggap dan mau memperhatikan apa yang diperlukan. Menurut Sarason (1983) dukungan sosial diartikan sebagai informasi verbal atau non verbal, saran, bantuan nyata, tingkah laku yang diberikan oleh orang-orang yang akrab dengan subjek di dalam lingkungan sosialnya atau yang berupa kehadiran dan hal-hal yang dapat memberikan keuntungan emosional atau berpengaruh terhadap tingkah laku penerimanya. Dukungan sosial adalah keberadaan, kesediaan, kepedulian dari orang-orang yang dapat diandalkan, menghargai, dan menyayangi.

Katc dan Kahn (dalam Suparyanto, 2011) berpendapat bahwa dukungan sosial adalah perasaan positif, menyukai, kepercayaan, perhatian, pengakuan, dan bantuan langsung dalam bentuk tertentu dari orang lain, yaitu orang yang berarti dalam kehidupan individu yang bersangkutan. Dukungan sosial merupa-kan transaksi interpersonal yang mencakup afeksi positif, penegasan dan bantuan. Dukungan sosial pada umumnya menggambarkan peranan atau pengaruh yang dapat ditimbulkan oleh orang lain yang berarti seperti anggota keluarga, teman, saudara, dan rekan kerja. Taylor (2009) berpendapat bahwa dukungan sosial adalah informasi dari orang lain yang memberikan perhatian dan merupakan bagian dari jaringan komunikasi serta saling memiliki kewajiban.

Berkaitan dengan sumber dukungan sosial, Kahn \& Antonoucci (dalam Orford, 1992) membaginya menjadi tiga kategori. Pertama, sumber dukungan sosial yang stabil sepanjang waktu, misalnya keluarga dekat, pasangan (suami/isteri), atau teman dekat. Kedua, sumber dukungan sosial 
yang berasal dari individu lain yang sedikit berperan dalam hidupnya dan cenderung berubah, misalnya teman kerja, tetangga, sanak kelaurga dan teman sepergaulan. $\mathrm{Ke}$ tiga, sumber dukungan sosial yang berasal dari individu lain yang sangat jarang memberi dukungan.

Dalam konteks kedisiplinan beribadah, sumber dukungan dapat berasal dari orang lain yang mempunyai kelekatan hubungan yang dihayati atau karena ada hubungan darah, seperti: suami-isteri, orang tua-anak, saudara sekandung, atau keluarga satu trah. Sumber dukungan sosial juga dapat berasal dari tetangga, sesama warga gereja yang telah terikat dalam sebuah persaudaraan, majelis gereja.

House (dalam Smet, 1994) mengemukakan empat aspek dukungan sosial. Pertama, emosional, yaitu ungkapan perasaan berupa perhatian, mengajak, meng-ingatkan dan mendorong untuk melakukan suatu tindakan yang baik. Kedua, instrumental, meliputi penyediaan sarana untuk mempermudah atau menolong orang lain sebagai contohnya adalah peralatan, perlengkapan, dan sarana pendukung lain dan termasuk didalamnya memberikan peluang waktu. Ketiga, informasi, terdiri dari pemberian nasihat, pengarahan, dan keterangan lain yang dibutuhkan oleh individu yang bersangkutan. Keempat, penilaian, terdiri atas dukungan peran sosial yang meliputi umpan balik, perbandingan sosial, dan afirmasi (persetujuan).

Dalam konteks kedisiplinan beribadah, dukungan emosional merupakan ungkapan perasaan yang diterima dari keluarga, teman dekat, sahabat, sesama warga gereja, atau majelis gereja yang berupa perhatian, mengajak, mengingatkan, dan mendorong individu untuk beribadah. Instrumental yang diterima dalam bentuk peralatan, perlengkapan, dan sarana seperti Alkitab, buku nyanyian, uang persembahan dan pemberian bantuan transportasi bagi warga gereja yang memerlukan untuk mempermudah dan memperlancar dalam melaksanakan ibadah. Dukungan informasi berupa nasihat, pengarahan dan keterangan lain yang dibu- tuhkan untuk mendukung kedisiplinan beribadah. Dukungan penilaian berupa umpan balik seperti apresiasi kepada warga gereja yang memiliki kedisiplinan tinggi dalam beribadah, melakukan kedisiplinan ibadah seperti yang dilakukan oleh orang lain dan memberikan peneguhan kepada warga gereja yang telah melakukan kedisiplinan.

Dalam penelitian ini dukungan sosial diungkap melalui aspek-aspek seperti yang dikemukakan oleh House (dalam Smet, 1994). Semakin tinggi skor subjek maka semakin tinggi dukungan sosial yang diterima, sebaliknya semakin rendah skor subjek maka semakin rendah dukungan sosial yang diterima subjek.

\section{METODE}

Penelitian ini adalah penelitian kuantitatif meliputi variabel terikat kedisiplinan beribadah dan variabel bebas orientasi religius dan dukungan sosial.

Kedisiplinan beribadah diungkap melalui aspek-aspek disiplin yang mengacu teori Irmim dan Rochim (2004) yaitu aspek sikap mental (sikap taat, tertib dan pengendalian diri); aspek pemahaman atau kesadaran, dan aspek sikap kesungguhan hati. Orientasi religius diungkap dengan mengacu teori Allport dan Ross, yaitu orientasi religius ekstrinsik-intrinsik yang dikembangkan oleh Hunt dan King (dalam Widyana, 1995), melalui aspek-aspek: personal-institusional, unselfish-selfish, relevansi terhadap keseluruhan kehidupan, kepenuhan penghayatan keyakinan, pokok-instrumental, asosiasional-komunal, dan keteraturan penjagaan perkembangan iman. Dukungan sosial diungkap melalui aspek-aspek yang dikemukakan oleh House (dalam Smet, 1994) yaitu emosional, instrumental, informasi, dan penilaian.

Subjek penelitian adalah warga Gereja Kristen Jawa Ngento-ento yang dewasa. Jumlah responden 81 orang atau $25 \%$ dari populasi, terdiri dari 47 orang laki-laki $(58,02 \%)$ dan 34 orang perempuan $(41,98 \%)$; dewasa muda(18-40 tahun) 22 orang $(27,16 \%)$, dewasa madya (41-60 tahun) 42 orang 
(51,85\%), dan dewasa akhir (60 tahun ke atas) 17 orang $(20,99 \%)$.

Pengumpulan data dilakukan dengan skala sesuai variabel yang diteliti. Skala dibuat dengan mengikuti teori Likert dengan menghilangkan alternatif jawaban tengah. Respons subjek disediakan empat kategori yang harus dipilih salah satu yang sesuai dengan keadaan dirinya secara jujur. Pilihan jawaban untuk aitem favourable diberi skor: sangat sesuai 4 , sesuai 3 , kurang sesuai 2 , tidak sesuai 1; jawaban aitem unfavourable: sangat sesuai 1 , sesuai 2 , kurang sesuai 3 , tidak sesuai 4.

Menurut Azwar (2008), aitem yang mencapai koefisien korelasi minimal 0,30 daya pembedanya dianggap memuaskan, tetapi bisa diturunkan hanya saja tidak kurang dari 0,20. Emery (dalam Azwar, 2008) menggunakan pedoman dari US Department of Labor, Employment Training and Administration, bahwa alat ukur yang memiliki koefisien korelasi $\geq 0,21$ dapat digunakan. Reliabilitas alat ukur diuji dengan teknik formula Cronbach Alpha.

Skala kedisiplinan beribadah dari 30 aitem yang diujicoba ada 26 aitem yang valid, koefisien korelasi antara 0,232-0,616, reliabilitas 0 , 850. Skala orientasi religius dari 28 aitem yang diuji coba, yang valid 16 aitem dengan koefisien korelasi antara $0,219-0,585$. reliabilitas 0,769 . Skala dukungan sosial dari 24 aitem yang diuji coba, yang valid 17 aitem dengan koefisien korelasi antara 0,217-0,558. reliabilitas 0,795. Ketiga macam skala sebagai alat ukur penelitian telah memenuhi persyaratan validitas dan reliabilitas dan telah meliputi aspekaspek variabel yang diteliti.

Analisis data dengan teknik korelasi product moment dan teknik regresi linier berganda Proses pengolahan data dilakukan dengan perangkat lunak program SPSS 17. Analisis data untuk mengetahui perbedaan kedisiplinan beribadah antara kelompok laki-laki dan perempuan, serta kelompok usia dewasa muda, dewasa madya dan dewasa akhir menggunakan Independent Sample T-Test.
Pelaksanaan penelitian: uji coba skala 17-20 Oktober 2012. Penyebaran skala dan pengambilan data 22-29 Oktober 2012, analisis data dan pembahasannya 30 oktober - 10 Nopember 2012.

\section{HASIL DAN PEMBAHASAN}

Data variabel kedisiplinan beribadah responden, skor minimal hipotetik 26 , skor maksimal 104; mean 65, standar deviasi sebesar 13. Skor minimal empirik sebesar 67 , skor maksimal sebesar 101; mean sebesar 84 dan standar deviasi sebesar 5, 67.

Variabel orientasi religius, skor minimal hipotetik 16, skor maksimal 64; mean 40, standar deviasi sebesar 8. Skor minimal empirik sebesar 42, skor maksimal sebesar 64; mean sebesar 53 , standar deviasi sebesar 3, 67.

Variabel dukungan sosial, skor minimal hipotetik 17, skor maksimal 68; mean sebesar 42,5 standar deviasi sebesar 8,5. Skor minimal empirik sebesar 44, skor maksimal sebesar 66; mean sebesar 55 standar deviasi sebesar 3, 67 .

Berdasarkan nilai mean dan satuan standar deviasi, kategorisasi skor untuk kedisiplinan beribadah, orientasi religius, dan dukungan sosial dikelompokkan menjadi 3 bagian: tinggi, sedang dan rendah (Azwar, 2008). Subjek dengan kedisiplinan beribadah kategori tinggi 73 orang $(90,12 \%)$, sedang 8 orang $(9,88 \%)$, dan rendah tidak ada. Subjek dengan orientasi religius kategori intrinsik 69 orang (85,19\%), sedang 12 orang $(14,81 \%)$, dan kategori ekstrinsik tidak ada. Subjek dengan dukungan sosial kategori tinggi 57 orang (70,37\%), sedang 24 orang $(29,63 \%)$, dan yang rendah tidak ada.

Uji asumsi dasar meliputi uji normalitas dan linieritas data, untuk mengetahui distribusi data normal atau tidak serta untuk mengetahui hubungan orientasi religius dan dukungan sosial dengan kedisiplinan beribadah linier atau tidak (Azwar, 2008).

Uji normalitas data dengan metode Kolmogorov Smirnov program SPSS 17.0. Penilaian hasil pengujian ditetapkan de- 
ngan kaidah: jika nilai signifikansi $>0,05$ data berdistribusi normal, jika nilai signifikansi $<0,05$ data tidak berdistribusi normal (Santoso, 2001).

Hasil uji normalitas data menunjukkan bahwa nilai KS-Z variabel kedisiplinan beribadah 0,581, nilai signifikansi 0,888; orientasi religius 0,766 , nilai signifikansi 0,601 dan dukungan sosial 0,783, nilai signifikansi 0,572, dengan demikian data berdistribusi normal.

Uji Linieritas data dengan teknik uji ANOVA, SPSS 17.0. Jika nilai signifikansi $(\mathrm{p}<0.05)$ maka sebaran data linier (Santoso, 2001). Hasil uji linieritas variabel orientasi religius terhadap kedisiplinan beribadah nilai F 95,828 signifikansi 0,000<0,05, hubungan linier. Variabel dukungan sosial terhadap kedisiplinan beribadah menunjukkan nilai F 26,799, signifikansi 0,000<0,05, hubungan linier. kan:

Hasil analisis uji Hipotesis menunjuk-

1) Orientasi religius memiliki hubungan positif dengan kedisiplinan beribadah, dengan nilai korelasi $0,700(\mathrm{p}<0,05)$.

2) Dukungan sosial memiliki hubungan positif dengan kedisiplinan beribadah, dengan nilai korelasi $0,471(\mathrm{p}<0,05)$.

3) Ada hubungan positif secara bersamasama antara orientasi religius dan dukungan sosial dengan kedisiplinan beribadah. Hasil analisis menunjukkan persamaan regresi sebesar $\mathrm{Y}=18,841+$ $0,943 \mathrm{X}_{1}+0,336 \mathrm{X}_{2 .}$ Hasil uji F menunjukkan nilai F sebesar 44,916 (p 0,000< $0,05)$.

Hasil uji t untuk hubungan orientasi religius dengan kedisiplinan beribadah menunjukkan t sebesar 7,252 $(\mathrm{p}<0,05)$ sehingga orientasi religius secara parsial berpengaruh terhadap kedisiplinan beribadah. Sedangkan hubungan dukungan sosial dengan kedisiplinan beribadah menunjukkan nilai t sebesar 2,773 $(\mathrm{p}<0,05)$ sehingga dukungan sosial secara parsial juga berpengaruh terhadap kedisiplinan beribadah.

Koefisien Determinasi $\left(\mathrm{R}^{2}\right)$ sebesar 0,535 , dengan demikian variabel orien-tasi religius dan dukungan sosial telah memberikan sumbangan sebesar 53, 5\% terhadap kedisiplinan beribadah, sedangkan 46,5\% merupakan pengaruh variabel lain yang tidak diteliti.

Analisis uji beda dengan Independent Sample T-Test dan uji homoginitas dari Lavene's Test for Equality of variances. Sedangkan uji beda secara bersama-sama antara dewasa muda, dewasa madya dengan dewasa akhir dilakukan dengan metode analisis Anova.

Hasil analisis perbedaan kedisi-plinan beribadah antara laki-laki dan perempuan menunjukkan $\mathrm{F}$ 0,137 dengan $\mathrm{p}=0,712$ berarti data homogin, dan nilai $t=0,673$ dengan $p=0,503$. Karena $p>0,05$ maka dapat dikatakan bahwa tidak ada perbedaan signifikan antara laki-laki dan perempuan dalam hal kedisiplinan beribadah.

Hasil analisis perbedaan kedisi-plinan beribadah antara kelompok dewasa muda dan kelompok dewasa madya: data homogin $\mathrm{F}=0,020$ dengan $\mathrm{p}=0,887$. Nilai $\mathrm{t}=2,826$ dengan $p=0,006$, berarti ada perbedaan signifikan. Mean kelompok dewasa muda 83,58 dan mean kelompok dewasa madya 88,83. Kedisiplinan beribadah warga gereja kelompok dewasa madya ternyata lebih tinggi.

Hasil analisis perbedaan kedisiplinan beribadah kelompok dewasa muda dan kelompok dewasa akhir menunjukkan bahwa data homogin dengan $F=0,315$ dan $p=0,578$. Nilai t $=0,131 p=0,897$ berarti tidak ada perbedaan signifikan, mean 83,58 - 83,82

Hasil analisis perbedaan kedisiplinan beribadah kelompok dewasa madya dan kelompok dewasa akhir menunjukkan $\mathrm{F}=$ 0,195 dengan $p=661$, data homogin. Nilai $\mathrm{t}=2,580(\mathrm{p}<0,05)$, berarti ada perbedaan signifikan. mean 88,83-83,82.

Hasil analisis perbedaan secara bersama-sama dengan metode analisis Anova menunjukkan nilai $\mathrm{F}=5,742(\mathrm{p}<0,05)$. Dengan demikian dapat di-katakan ada perbedaan yang signifikan antara kelompok dewasa muda, dewasa madya dan dewasa akhir.

Hipotesis pertama yang diajukan bahwa ada hubungan positif dan signifikan antara 
orientasi religius dengan kedisiplinan beribadah diterima, nilai korelasi sebesar 0,700 $(\mathrm{p}<0,05)$. Hubungan yang dimaksud adalah bahwa semakin intrinsik orientasi religius subjek maka semakin tinggi kedisiplinan beribadah subjek. Sebaliknya, semakin ekstrinsik orientasi religius subjek, maka semakin rendah kedisiplinan beribadah subjek.

Individu dengan orientasi religius intrinsik melaksanakan kedisiplinan beribadah dengan motivasi dan kesadaran sebagai pelaksanaan perintah agama. Keyakinan religius menjadi pemandu dan pengarah yang tercermin dalam kehidupan seharihari termasuk dalam melaksanakan ibadah dengan kedisiplinan. Individu yang berorientasi religius ekstrinsik cenderung tanpa penghayatan yang benar, merasa nyaman meskipun terlambat menghadiri ibadah, mengantuk ketika berdoa atau mendengarkan khotbah, pulang sebelum ibadah usai, atau tidak terlibat aktif dalam seluruh unsurunsur ibadah.

Dari hasil penelitian dapat disimpulkan bahwa warga Gereja Kristen Jawa Ngentoento memiliki orientasi religius yang cenderung intrinsik, yang diperlihatkan melalui kedisiplinan beribadah yang tinggi. Mereka beribadah dengan ketaatan, ketertiban, dan dengan pemahaman serta kesungguhan hati; tidak untuk mencari kenyamanan dan penilaian baik dari orang lain.

Hipotesis kedua, bahwa ada hubungan positif dan signifikan antara dukungan sosial dengan kedisiplinan beribadah juga diterima, nilai korelasi sebesar 0,471 ( $\mathrm{p}<0,05)$. Hubungannya adalah bahwa semakin tinggi dukungan sosial yang diterima subjek, maka semakin tinggi kedisiplinan beribadah subjek. Sebaliknya, semakin rendah dukungan sosial yang diterima subjek, maka semakin rendah kedisiplinan beribadah subjek. Hasil penelitian ini sejalan dengan pendapat Zanden (1984) yang mengemukakan bahwa kehidupan manusia berisi interaksi sosial yaitu suatu proses yang diarahkan, dirangsang, dipengaruhi oleh orang lain atau orangorang lain. Aronson (2005) juga mengatakan bahwa dukungan sosial adalah pengalaman menerima pertolongan dari orang lain seperti dari keluarga dan teman-teman.

Warga Gereja Kristen Jawa Ngento-ento yang hidup dalam kebersamaan, baik dalam keluarga, gereja, maupun masyarakat ternyata dalam kehidupannya terdapat interaksi saling mempengaruhi, saling memperhatikan, saling mengajak dan mengingatkan, saling mendorong dalam melaksanakan kewajiban termasuk dalam mewujudkan kedisiplinan beribadah. Dukungan terwujud dalam bentuk penyediaan sarana atau perlengkapan ibadah, bantuan transportasi yang dapat menunjang warga dalam mengupayakan kedisiplinan beribadah. Selain itu dukungan juga nampak dalam bentuk nasihat dan pengarahan.

Hipotesis ketiga bahwa ada hubungan positif secara bersama-sama antara orientasi religius dan dukungan sosial terhadap kedisiplinan beribadah warga gereja juga diterima. Hasil analisis regresi linier berganda menunjukkan persamaan regresi sebesar $\mathrm{Y}=18,841+0,943 \mathrm{X}_{1}+0,336 \mathrm{X}_{2}$. Hasil uji $\mathrm{F}$ menunjukkan nilai $\mathrm{F}$ sebesar 44,916 dan $\mathrm{p}<0,05$. Hubungannya adalah bahwa semakin intrinsik orientasi religius yang dimiliki subjek dan semakin tinggi dukungan sosial yang diterima subjek, maka semakin tinggi pula kedisiplinan beribadah subjek. Sebaliknya, semakin ekstrinsik orientasi religius subjek dan semakin rendah dukungan sosial yang diterima subjek, maka akan semakin rendah kedisiplinan beribadah subjek.

Hasil analisis koefisien determinasi $\left(\mathrm{R}^{2}\right)$ menunjukkan bahwa besar koefisien determinasi $\left(\mathrm{R}^{2}\right)$ adalah 0,535. Artinya variabel orientasi religius dan dukungan sosial diketahui telah memberikan sumbangan terhadap kedisiplinan beribadah sebesar $53,5 \%$ sedangkan yang $46,5 \%$ dapat diduga merupakan pengaruh variabel lain yang tidak diteliti misalnya pembawaan, motivasi, minat, kesadaran, dan pola pikir (Hendriyani, 2012).

Hasil uji $t$ menunjukkan bahwa orientasi religius secara parsial berpengaruh ter- 
hadap kedisiplinan beribadah, nilai t sebesar $7,252(\mathrm{p}<0,05)$; dukungan sosial secara parsial juga berpengaruh terhadap kedisiplinan ber-ibadah, nilai t sebesar 2,773 ( $\mathrm{p}<0,05)$.

Hasil penelitian ini sejalan dengan pendapat Muller (dalam Kieser, 1997) yang mengatakan bahwa kesadaran religius yang melekat dalam diri manusia merupakan awal dari orientasi religius. Individu dengan orientasi religius intrinsik, dalam banyak hal menem-patkan religi sebagai sumber yang mengalirkan bahan-bahan pengembangan diri dalam rangka pembentukan kualitas manusia serta kebahagiaan hidup. Kesadaran tersebut memunculkan tindakan yang bersifat mengarah kepada pengutamaan kepentingan religius, antara lain melalui pelaksanaan peribadahan secara disiplin. Sebagai aktivitas religius yang terkait dengan orientasinya maka kedisiplinan beribadah individu akan semakin disadari.

Juga sejalan dengan pendapat Dewey (dalam Haniah, 2001), yang mengatakan bahwa religius menunjukkan suatu sikap hidup yang terarah pada nilai-nilai ideal dalam religi. Perubahan sikap hidup berasal dari refleksi terhadap objek-objek duniawi yang merupakan penyesuaian yang berhubungan dengan keseluruhan keberadaan kita, baik perubahan diri sendiri maupun perubahan lingkungan di luar diri individu. Perubahan sikap tersebut antara lain dapat berupa kepatuhan yang muncul secara sukarela. Perubahan sikap ke arah kepatuhan tidak hanya dipengaruhi faktor internal tetapi juga lingkungan di luar diri individu. Lingkungan yang memberi dukungan secara positif, seperti perhatian, penghargaan, bantuan materi, atau arahan akan mendukung ke arah kepatuhan yang menjadi aspek dari kedisiplinan. Lingkungan yang tidak memberi dukungan, misalnya tidak ada perhatian, bantuan materi, atau arahan, akan memberi pengaruh yang berbeda yaitu ketidakpatuhan.

Warga Gereja Kristen Jawa Ngentoento merupakan individu yang memiliki kedisiplinan beribadah cenderung tinggi, melaksanakan ibadah dengan sikap taat, tertib, pengendalian diri, kesadaran, dan kesungguhan hati; menghayati segala bentuk ajaran agama, saling memberikan dukungan dalam menerapkan kedisiplinan beribadah, tidak untuk mencari rasa nyaman sosial dan penilaian baik dari masyarakat.

Dari hasil analisis tambahan ternyata diketahui bahwa kedisiplinan beribadah antara laki-laki dan perempuan tidak menunjukkan perbedaan yang signifikan. Matlin (dalam Taylor, 2009) mengemukakan bahwa ada perbedaan antara laki-laki dan perempuan dalam hal peran, pada umumnya laki-laki lebih ke peran sosial sedangkan perempuan lebih terbatas pada peran keluarga dan domestik. Laki-laki dan perempuan sebagai kategori paling dasar yang membedakan dalam kehidupan sosial dan penjenisan gender itu terjadi secara otomatis melalui karakter fisik dan selanjutnya merupakan bagian dari presentasi diri. Laki-laki pada umumnya digambarkan sebagai pemimpin, lebih aktif, asertif, berpengaruh dan perempuan sebagai subordinat.

Tetapi dalam hal aktivitas religius yang tampak dalam kedisiplinan beribadah warga gereja ternyata hasil penelitian menunjukkan tidak ada perbedaan yang signifikan antara laki-laki dan perempuan. Hyde (dalam Taylor, 2009) mengemukakan bahwa pada level kemampuan dasar dan motivasi dalam diri individu, perbedaan yang dilihat menurut gender biasanya kecil atau bahkan tidak ada, pria dan wanita memiliki kesamaan dalam banyak pembawaan dasar.

Hasil penelitian pada warga Gereja Kristen Jawa Ngento-ento ternyata baik lakilaki maupun perempuan sama-sama memiliki kedisiplinan beribadah yang cenderung tinggi. Warga gereja baik laki-laki maupun perempuan sama-sama memiliki kedisiplinan dalam kehadiran dan keaktifan melakukan unsur-unsur ibadah. Hasil analisis uji beda menurut kategori usia menunjukkan bahwa perbedaan signifikan itu ditemukan antara warga dewasa muda dengan dewasa madya dan antara dewasa madya dengan dewasa akhir. Sedangkan antara dewasa muda dengan dewasa akhir justru tidak 
ada perbedaan signifikan. Dari ketiga kelompok usia dewasa ternyata kedisiplinan beribadah yang tinggi adalah mereka yang berada pada usia dewasa madya (40-60 tahun). Pada manusia secara umum dikatakan oleh Fowler (dalam Crapps, 1994) bahwa iman merupakan orientasi dasar pada usia dewasa dan inti struktural keberadaan manusia. Iman oleh orang dewasa dipergunakan untuk cara berpikir dan membuat keputusan moral, keputusan tentang peran dan tempat autoritas. Perbedaan yang ditemukan dari penelitian sebenarnya tidak terlalu mencolok. Mengikuti teori Erikson (dalam Crapps, 1994) ciri-ciri individu sesuai dengan kelompok usia, dewasa muda dicirikan oleh pengalaman menggali keintiman, eksklusif, generativitas dan kekuatan dasarnya adalah cinta. Masa dewasa madya dicirikan oleh produktivitas maksimum, pro kreativitas, krisis psikososial, dan kekuatan dasarnya adalah perhatian dan pemeliharaan, melestarikan fungsi dan tanggung jawab, mengabadikan hidup dan kebudayaan yang menjadi maksud Tuhan, bersama Tuhan memelihara ciptaan. Sedangkan dewasa akhir (60 ke atas), dicirikan oleh menurunnya potensi fisik, integritas vs keputusasaan, kekuatan dasarnya adalah kebijaksanaan (wisdom).

Aktivitas yang mencirikan individu dewasa oleh Sherrill (dalam Crapps, 1994), dikemukakan bahwa dewasa muda merupakan tahap memilih arah hidup, penetapan peran dan keterlibatan. Dewasa madya menghadapi tantangan hidup sambil memantabkan tempat dan mengembangkan filsafat, mencapai pandangan hidup yang masak dan utuh yang menjadi dasar membuat keputusan secara konsisten. Dewasa akhir ciri utamanya adalah pasrah, minat dan kegiatan kurang beragam, hal-hal yang kurang penting dilepas demi hal-hal yang lebih penting, hidup menjadi kurang rumit dan lebih terpusat pada hal-hal yang sungguh berarti, kesederhanaan. Sedangkan Moberg (dalam Crapps, 1994) juga berpendapat bahwa individu usia lanjut, perasaan religius menjadi semakin intens, agama menjadi hal penting, orang tua religius cenderung konservatif dan intens terlibat dalam pandangan religiusnya.

Memperhatikan teori-teori tersebut di atas dapat dikatakan ada kesesuaian antara ciri-ciri yang dikemukakan dengan hasil analisis uji beda ketika kelompok dewasa. Dewasa madya menunjukkan kedisiplinan beribadah yang rata-ratanya adalah paling tinggi dibanding dengan dewasa muda dan dewasa akhir.

Secara keseluruhan hasil penelitian menyimpulkan bahwa warga Gereja Kristen Jawa Ngento-ento memiliki orientasi religius yang cenderung intrinsik, dukungan sosial yang cenderung tinggi, dan kedisiplinan beribadah juga cenderung tinggi. Dua variabel bebas yaitu orientasi religius dan dukungan sosial berhubungan positif dengan varabel terikat yaitu kedisiplinan beribadah warga gereja.

\section{SIMPULAN}

Berdasarkan hasil dan pembahasan penelitian dapat disimpulkan beberapa hal berikut.

Pertama, ada hubungan positif antara orientasi religius dengan kedisiplinan beribadah. Semakin intrinsik tingkat orientasi religius yang dimiliki oleh warga gereja, maka semakin tinggi kedisiplinan beribadah warga gereja, sebaliknya semakin ekstrinsik tingkat orientasi religius warga gereja maka semakin rendah kedisiplinan beribadah warga gereja.

Kedua, ada hubungan positif antara dukungan sosial dengan kedisiplinan beribadah. Semakin tinggi dukungan sosial warga gereja maka semakin tinggi kedisiplinan beribadah warga gereja, sebaliknya semakin rendah dukungan sosial warga gereja maka semakin rendah kedisiplinan beribadah warga gereja.

Ketiga, Ada hubungan secara bersamasama antara orientasi religius dan dukungan sosial dengan kedisiplinan beribadah. Sumbangan efektif variabel orientasi religius dan dukungan sosial terhadap kedisiplinan beribadah sebesar 53,5\%, sedangkan $46,5 \%$ 
dipengaruhi oleh faktor lain.

Berdasarkan simpulan di atas, dikemukakan saran-saran sebagai berikut:

Pertama, warga Gereja Kristen Jawa Ngento-ento agar meningkatkan orientasi religius ke arah intrinsik, meningkatkan dukungan sosial dalam keluarga dan dalam kelompok kegiatan gereja untuk meningkatkan kedisplinan beribadah.

Kedua, hasil penelitian telah membuktikan bahwa orientasi religius dan dukungan sosial menjadi faktor yang mempengaruhi perilaku kedisiplinan beribadah. Oleh karena itu penulis memberikan masukan bahan pertimbangan kepada Majelis Gereja Kristen Jawa Ngento-ento selaku penanggungjawab kegiatan warga gereja untuk menyampaikan materi kegiatan Pemahaman Alkitab yang mengarah pada orientasi religius dan dukungan sosial.

Ketiga, Sumbangan efektif yang diberikan oleh faktor orientasi religius dan dukungan sosial terhadap kedisiplinan beribadah adalah $53,5 \%$, sehingga $46,5 \%$ dipengaruhi oleh faktor-faktor lain yang tidak dilibatkan dalam penelitian ini. Maka kepada peneliti berikutnya disarankan untuk melakukan penelitian dengan melibatkan faktor-faktor lain seperti pembawaan, motivasi, minat, kesadaran, dan pola pikir.

Keempat, kelemahan penelitian ini adalah pada penyusunan skala orientasi religius meskipun semua aspek telah terwakili tetapi aspek personal-institusional dan unselfishselfish hanya terdiri dari aitem favourable, aspek keteraturan penjagaan perkembangan iman hanya terdiri dari aitem unfavourable. Oleh karena itu penulis menyarankan kepada peneliti selanjutnya agar dalam menyusun skala, setiap aspek dilengkapi dengan aitem favourable dan unfavourable.

\section{DAFTAR PUSTAKA}

Abineno, J.L.Ch. 1999. Pokok-pokok Penting dari Iman Kristen. Jakarta: PT BPK Gunung Mulia.

Anshari, H. 1983. Pengantar Ilmu Pendidikan. Surabaya: Usaha Nasional.
Arikunto, S. 1990. Managemen Pengajaran Secara Manusiawi. Jakarta: Rineka Cipta.

Arikunto, S. 2006. Prosedur Penelitian. Suatu Pendekatan Praktik. Jakarta: Rineka Cipta. Aronson, E., Wilson, T. D., Akert, R.M. 2005. Social Psychology. Fifth Edition. USA: Pearson Prentice Hall.

Azwar, S. 2008. Penyusunan Skala Psikologi. Edisi ke 1, Cetakan XI. Yogyakarta: Pustaka Pelajar.

Azwar, S. 2011. Reliabilitas dan Validitas. Yogyakarta: Pustaka Pelajar.

Brown, F. 1979. The New Hebrew and English Lexicon. USA: Hendrickson Publisher.

Chan, S. 1998. Spiritual Theology. Studi Sistematis tentang Kehidupan Kristen, Buku 2. Yogyakarta: Andi Ofset.

Chaplin, J.P. 2006. Kamus Lengkap Psikologi. Jakarta: PT Raja Grafindo Persada.

Crapps, R.W 1993. Gaya Hidup Beragama. Yogyakarta: Penerbit Kanisius.

Dister, N.S. 1982. Pengalaman dan Motivasi Beragama. Pengantar Psikologi Agama. Jakarta: Leppenas.

Douglas, J.D. 1999. Ensiklopedi Alkitab Masa Kini. Jakarta: Yayasan Komunikasi Bina Kasih/ OMF.

Drever, J. 1988. Kamus Psikologi. Jakarta: PT Bina Aksara.

Echols, M., Shadily, H. 2005. Kamus Inggris Indonesia. Jakarta: PT Gramedia Pustaka Utama.

Feist, J., Feist, G.J. 2008. Theories of Personality. Ed VI. Yogyakarta: Pustaka Pelajar.

Haniah. 2001. Agama Pragmatis. Telaah atas Konsepsi Agama John Dewey. Magelang: Indonesiatera.

Hardjana, AM. 1993. Penghayatan Agama yang Otentik dan Tidak Otentik. Yogyakarta: Kanisius.

Heitink, G., Hartono SJ, F.H. 1999. Teologi Praktis Pastoral dalam Era Modernitas Post Modernitas. Yogyakarta: Kanisius.

Hendriyani, N. 2012. lib.uin-malang.ac.id/ thesis/chapter_ii/07110076-nani-hendriyani.ps

Hermapramni, S. 2012. Hubungan antara Orientasi religius dan Kebermaknaan 
hidup dengan Sikap dalam Menghadapi Masalah Keluarga. Tesis. Yogyakarta: Universitas Mercu Buana Yogyakarta.

Heuken SJ, A. 2004. Ensiklopedi Gereja. Jilid I A-B. Jakarta: Yayasan Cipta Loka Caraka.

Irmim, S. \& Rochim, A. 2004. Membangun Disiplin Diri Melalui Kecerdasan Spiritual dan Emosional. Jakarta: Batavia Press.

Kieser, B. 1997. Agama dan Proses Perkembangan Moral. Jurnal IImu dan Kebudayaan UNISIA No.35/XX/III/1997 h. 50.

Moeliono, A.M. 1990. Kamus Besar Bahasa Indonesia. Jakarta: Balai Pustaka.

Orford, J. 1992. Community Psychology: Theory and Practice. England: John Wiley \& Sons.

Peck, M. S. 2007. Psikologi Baru. Pengembangan Diri. Yogyakarta: Penerbit BACA.

Peschke SVD., Heinz, K. 2003. Etika Kristiani Jilid II. Kewajiban Moral dalam Hidup Keagamaan. Maumere: Penerbit Ledalero.

Prijodarminto, S. 1994. Disiplin Kiat Menuju Sukses. Jakarta: Pradnya Paramita.

Sarason, I.G., Levine, H.M., Basham, R.B., \& Sarason, B.R. 1983. Assessing Social Support: The Social Support Questionare. Journal of Personality and Social Psychology, 60 273-287.

Sastropoetro, S. 1998. Partisipasi, Komunikasi, Persuasi dan Disiplin dalam Pembangunan Nasional. Bandung: Penerbit Alumni.
Setiawan, B. 1997. Ensiklopedi Nasional Indonesia. Jakarta: P.T. Delta Pamungkas.

Sinclair, J. 2001. English Dictionary for Edvanced Learners. England: Harper Collins Publishers.

Sinode GKJ. 2005. Tata Gereja dan Tata Laksana Gereja Kristen Jawa. Salatiga: Sinode GKJ.

Smet. 1994. Psikologi Kesehatan. Jakarta: PT Grasindo.

Stott, J. 1996. Isu-isu Global Menantang Kepemimpinan Kristiani. Jakarta: Yayasan Komunikasi Bina Kasih - OMF.

Subandrijo, B. 2003 Agama dalam Praksis. Jakarta: BPK Gunung Mulia; Yayasan Widya Bhakti.

Suparyanto. 2011. Dukungan Sosial. http:// dr-suparyanto.blogspot.com/ 2011/05/ konsep-dukungan.html. Diunduh tanggal 1 Otober 2012.

Suseno, FM. 1988. Kuasa dan Moral. Jakarta: Gramedia.

Taylor, S. E., Peplau,L.A., \& Sears, D.O. 2009. Psikologi Sosial. Ed. 12. Jakarta: Kencana Perdana Media Group.

Taylor, S. E. 2009. Health Psychology. New York: McGraw-Hill Company, Inc.

White, J. F. 2002. Pengantar Ibadah Kristen. Jakarta: BPK Gunung Mulia.

Widyana, R. 1995. Orientasi Keagamaan dan Afek pada Mahasiswa Muslim Universitas Gadjah Mada. Skripsi. Yogyakarta: Universitas Gajah Mada.

Zanden, J.W.V. 1984. Social Psychology. New York: Random House Inc. 